Original Research Paper

\title{
Effect of Organic Fertilizer on Growth and Productivity of Ipomoea reptans Poir
}

\author{
Klementinus Bhato $^{1^{*}}$, Yohanes Bare ${ }^{1}$, Oktavius Yoseph Tuta Mago ${ }^{1}$ \\ ${ }^{1}$ Program Studi Pendidikan Biologi, Universitas Nusa Nipa Indonesia, Maumere, Indonesia
}

\author{
Article History \\ Received : December 05 ${ }^{\text {th }}, 2021$ \\ Revised : December $15^{\text {th }}, 2021$ \\ Accepted : December $27^{\text {th }}, 2021$ \\ Published : January $07^{\text {th }}, 2022$ \\ *Corresponding Author: \\ Klementinus Bhato, \\ Program Studi Pendidikan \\ Biologi, Universitas Nusa Nipa \\ Indonesia, Maumere, Indonesia; \\ Email: klemensbhato96@gmail.com
}

\begin{abstract}
Kangkung Darat (Ipomoea reptans Poir) is the vegetable that is popular and consumed by the community. Chemical fertilizers bring negative impacts on soil and consumer health, lead to change thewith liquid organic fertilizer from cattle dung and tofu industrial waste with floating raft hydroponic planting techniques. The purpose of this study was to analyze the effect of liquid organic fertilizer on the growth and productivity of Ipomoea reptans Poir. The research was conducted on the campus of the University of Nusa Nipa Indonesia. The research method, quantitative data collection using a Randomized Block Design (RAK) consisting of 5 treatments, namely $\mathrm{P} 0=0 \%$ (control), $\mathrm{P} 1=20 \%, \mathrm{P} 2=$ $40 \%, \mathrm{P} 3=60 \%, \mathrm{P} 4=80 \%$. Parameters observed were plant height, number of leaves and wet weight. The data obtained were analyzed using SPSS version 16.0 with an advanced test, namely the DMRT (Duncan's Mutiple Range Test) test. The results showed that the application of liquid organic fertilizer from cow dung and tofu industrial waste had a significant effect on the growth and productivity of Ipomoea reptans Poir. The effects include the growth of plant height and number of leaves as well as the yield of Ipomoea reptans Poir including wet weight (fresh) with the best concentration of P2 treatment with $40 \%$ POC concentration This research provides benefits for the community, especially the potential as farmers to further motivate the use of liquid organic fertilizer made from cow dung and tofu waste to increase crop income and soil fertility.
\end{abstract}

Keywords: cattle dung, Ipomoea reptans Poir, liquid organic fertilizer, rak, tofu

\section{Pendahuluan}

Ipomoea reptans Poir tergolong tanaman hortikultura yang mengandung vitamin, protein, kalsium, fosfor, sitosterol dan mineral terutama zat besi. Kandungan organik Ipomoea reptans Poir lebih banyak dari pada cair hasil pengolahan feses dan urine ternak. Tanaman ini termasuk kelompok tanaman semusim yang berumur pendek dan tidak memerlukan areal yang luas untuk membudidayakannya (Irawati dan Salamah, 2013). Produksi Ipomoea reptans Poir ditingkat petani masih tergolong rendah, sehingga dalam pembudidayaan Ipomoea reptans Poir membutuhkan pupuk untuk mengoptimalkan pertumbuhan dan hasil panen (Febriyono et al., 2017). Dalam rangka peningkatan produksi Ipomoea reptans Poir perlu dilakukan upaya inovasi dalam proses pertumbuhan dan perkembangan. Salah satunya dengan memanfaatkan pupuk sebagai salah satu sumebr nutrisi. Pemanfaatan pupuk dalam jangka lama terbukti telah menimbulkan masalah serius, semenjak para petani menggunakan pupuk anorganik antara lain pencemaran tanah, air, penurunan tingkat kesuburan tanah dan ketergantungan petani secara ekonomi dan sosial (Ahmad et al., 2019; Hidayat, 2019). Penggunaan pupuk anorganik juga memiliki dampak berbahaya bagi kesuburan tanah dan kesehatan manusia, sehingga diperlukan budidaya tanama secara organik untuk mengurangi dampak tersebut.

Proses transformasi dari pupuk anoragnik dilakukan karena beberapa tanaman diprediksi memiki bahan aktif pupuk. Pupuk cair 
merupakan pupuk mengalami fermentasi berupa cairan (Bahan kimia 5\%). Penggunaan pupuk organik cair (POC) memiliki beberapa kelebihan yaitu pengaplikasiannya diserap tanaman dengan lebih mudah, mengandung mikroorganisme yang banyak, mengatasi defisiensi hara, mampu menyediakan hara secara cepat dan proses pembuatannya memerlukan waktu yang lebih cepat (Hidayat, 2019). Pupuk organik ini dapat diperoleh petani dengan cara memanfaatkan kotoran ternak seperti campuran kotoran sapi dan limbah industri tahu. Bahan-bahan tersebut dapat melepaskan unsur hara untuk kebutuhan tanaman sehingga dapat dimanfaatkan dalam proses pertumbuhan material kesehatan (Affandi et al., 2018; Krisnamurti et al., 2021; Sari \& Bare, 2020). Dalam rangka menjaga dan melestarikan budidaya tanaman dengan teknik hidroponik ini agar terus berkembang, maka diperlukan teknikteknik hidroponik yang lebih sederhana dan menekan biaya serta mudah diaplikasikan di masyarakat luas. Selain teknik-teknik sederhana dan media tanam dalam melakukan budidaya hidroponik, hal yang perlu diperhatikan dan sangat vital perannya dalam budidaya hidroponik adalah air dan nutrisi bagi tanaman (Solihin, 2015).

Beberapa penelitian yang menjelaskan pemenfaatan teknik hidroponik. Penelitian Zulfa (2019), menjelaskan bahwa pemanfaatan limbah cair tahu berpengaruh terhadap pertumbuhan Alternantera amoena Voss) hasil terbaik limbah cair tahu terdapat pada perlakuan P3 (60\%). Abdillah (2017), perlakuan pupuk AB Mix P0 kontrol menghasilkan pertumbuhan terbaik, Bramasto et al., (2020), limbah cair tahu memiliki pengaruh yang signifikan terhadap pertumbuhan bibit. Penelitian ini menggunakan pupuk organik cair dari hasil fermentasi kotoran sapi dan limbah tahu, yang diberikan pada Ipomoea reptans Poir dengan teknik hidroponik. Tujuan Penelitian ini adalah mengalisis Pengaruh Pupuk Organik Cair Terhadap Pertumbuhan Dan Produktivitas Ipomoea reptans Poir.

\section{Bahan dan Metode}

\section{Waktu dan Tempat Penelitian}

Pelaksanaan penelitian tanggal 1 Juni-04 Agustus 2021. Proses pembuatan hidroponik dan fermentasi secara anaerob berlangsung di
Laboratorium Fakultas Keguruan dan Ilmu Pendidikan Universitas Nusa Nipa Indonesia.

\section{Desain Penelitian}

Penelitian ini dirancang menggunakan rancangan acak kelompok (RAK) yang terdiri atas 5 taraf perlakuan dan dibuat dalam4 kelompok, sehingga terdapat 20 unit percobaan.

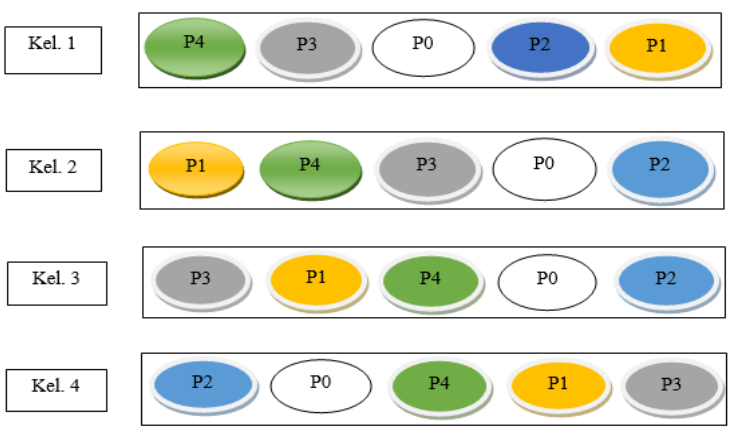

Gambar 1. Tata letak percobaan.

\section{Persiapan Pembuatan Pupuk Organik Cair (POC)}

Bahan baku kotoran sapi ditambah air dan limbah industri tahudengan komposisi 13,6 liter kotoran sapi $+3,4$ liter limbah industri tahu. Kemudia dicampurkan secara merata dalam wadah. Bahan isian yang sudah diaduk merata dimasukan kedalam digester dari volume digester 30 liter sebanyak 22 liter. Pupuk organik cair didapatkan dari hasil pembuatan biogas dengan lama fermentasi 62 hari (2bulan) Misa (2021). Setelah adonan dibiarkan selama 31 hari, adonan disaring menggunakan kain dan air hasil saringan dimasukan kedalam ember matex yang ditutup rapat dan dijadikan POC.

\section{Tahap Pengukuran Komposisi}

POC inokulum kotoran sapi dan limbah tahu dengan komposisi, $\mathrm{P} 0=2000 \mathrm{ml}$ air, $\mathrm{P} 1=$ $400 \mathrm{ml}$ liter POC inokulum kotoran sapi dan limbah tahu $+1600 \mathrm{ml}$ air, P2= $800 \mathrm{ml}$ POC inokulum kotoran sapi dan limbah tahu +1200 $\mathrm{ml}$ air, P3= $1200 \mathrm{ml}$ POC inokulum kotoran sapi dan limbah tahu $+800 \mathrm{ml}$ air, $\mathrm{P} 4=1600 \mathrm{ml}$ POC inokulum kotoran sapi dan limbah tahu $+400 \mathrm{ml}$ air. Kemudian dicampur dan diaduk secara merata didalam wadah (Zulfa, 2019).

\section{Persiapan Media Tanam}


Media tanam dibuat menggunakan net pot. Net pot diletakan pada styrofoam yang telah dilubangi sehingga bagian bawa net pot menyentuh permukaan larutan nutrisi (Fadhlillah et al., 2019), sedangkan pembuatan hidroponik rakit apung diadopsi dari penelitian Qoniah, (2019) sedangkan proses pertumbuhan dan parameter pengukur diadopsi penelitian Putri, (2017).

\section{Parameter Pengamatan}

Pengamatan parameter tinggi dan jumlah daun dilakukan pada 0 HST, 7 HST, 14 HST, 21 HST, 28 HST, 35 HST meliputi tinggi tanaman, jumlah helaian daun (Zulfa, 2019) dan berat basah secara langsung setelah panen (35 HST) (Swastini, 2015).

\section{Analisis Data}

Analisis data menggunakan Aplikasi SPSS 16.0. $\mathrm{P} \leq 0,05$ hipotesis diterima; jika $\mathrm{P}>0,05$ maka hipotesis ditolak (Arba'i, 2021). Cara mengambil kesimpulan adalah: Jika $\mathrm{P} \leq 0,05$ maka akan dilanjutkan uji lanjutan yaitu Uji DMRT (Duncan's Mutiple Range Test).

\section{Hasil dan Pembahasan}

Pupuk organic cair (POC) berpengaruh terhadap pertumbuhan dan prosuktivitas secara signifikan terhadap Ipomoea reptans Poir.

\section{Pertumbuhan Tanaman Ipomoea reptans Poir}

Pola pertumbuhan tinggi dan jumlah daun tanaman mengalami peningkatan mulai 7 HST-
35 HST merupakan fase pertumbuhan vegetatif. Pada hari 14 HST pertumbuhan tinggi dan jumlah daun pada perlakuan P0, P3 dan P4 mengalami perlambatan hingga 35 HST. Perlambatan pertumbuhan ini menurut Manuel, (2017) menyatakan bahwa unsur N merupakan unsur dalam proses metabolism protein fungsional berfungsi menstimulus pertumbuhan. Apabila tanaman kekurangan nitrogen maka daun akan menguning, mengering dan rontok karena kekurangan klorofil. Secara alami tanaman tersebut memaksa diri untuk menggugurkan daunnya tujuan untuk memperlambat proses transpirasi (proses kehilangan air pada tumbuhan) demi menghemat konsumsi air. Berdasarkan hasil analisis statistik perlakun P2 mendominasi hasil terbaik untuk semua parameter baik tinggi, jumlah daun maupun berat basah Ipomoea reptans Poir. Hasil terbaik selanjutnya perlakuan P1 dengan konsentrasi POC 20\%, dilanjutkan P3 dengan kosentrasi POC $60 \%$, perlakuan $\mathrm{P} 4$ dengan konsentrasi POC $80 \%$ dan P0 (kontrol) pada parameter penelitian.

\section{Tinggi Tanaman Ipomoea reptans Poir}

Pengukuran tinggi Ipomoea reptans Poir dimulai dari 10 HSS hingga 35 HST. Berdasarkan data hasil pengamatan pemberian POC kotoran sapi dan limbah tahu hasil produksi biogas berpengaruh terhadap tinggi Ipomoea reptans Poir perlakuan P0 (kontrol) $=25,7625$ $\mathrm{cm}$. Pemberian POC perlakuan P1 $=43,75625$ $\mathrm{cm}$, perlakuan $\mathrm{P} 2=45,59375 \mathrm{~cm}$, perlakuan $\mathrm{P} 3$ $=36,9625 \mathrm{~cm}$ dan $\mathrm{P} 4=36,95 \mathrm{~cm}$ (Tabel 1).

Tabel 1. Data hasil pengamatan rata-rata tinggi Ipomoea reptans Poir

\begin{tabular}{ccccccc}
\hline \multirow{2}{*}{ Perlakuan } & \multicolumn{5}{c}{ Rata-Rata Tinggi Tanaman Kangkung Darat (Ipomoea reptans Poir) (cm) } \\
\cline { 2 - 7 } & 10 HSS & 7 HST & 14 HST & 21 HST & 28 HST & 35 HST \\
\hline P0 & 8,96875 & $11,4125^{\mathrm{a}}$ & $18,84375^{\mathrm{a}}$ & $20,81875^{\mathrm{a}}$ & $22,85625^{\mathrm{a}}$ & $25,7625^{\mathrm{a}}$ \\
P1 & 8,80625 & $11,49375^{\mathrm{ab}}$ & $19,9125^{\mathrm{a}}$ & $27,86875^{\mathrm{b}}$ & $39,75625^{\mathrm{cd}}$ & $43,75625^{\mathrm{c}}$ \\
P2 & 10,36875 & $13,475^{\mathrm{b}}$ & $23,73125^{\mathrm{b}}$ & $29,54375^{\mathrm{b}}$ & $43,18125^{\mathrm{d}}$ & $45,59375^{\mathrm{c}}$ \\
P3 & 9,59375 & $11,9125^{\mathrm{ab}}$ & $20,4425^{\mathrm{ab}}$ & $26,65^{\mathrm{b}}$ & $34,51875^{\mathrm{bc}}$ & $36,9625^{\mathrm{b}}$ \\
P4 & 9,00375 & $12,2325^{\mathrm{b}}$ & $21,61875^{\mathrm{ab}}$ & $27,7035^{\mathrm{b}}$ & $32,77475^{\mathrm{b}}$ & $36,95^{\mathrm{b}}$
\end{tabular}

Keterangan: Nilai rata-rata yang diberi superscrip menunjukan bahwa hasil tersebut signifikan, menurut uji DMRT (Duncan's Mutiple Range Test) 
Tinggi Ipomoea reptans Poir berpengaruh nyata pada pada hari yang ke 35 HST dengan hasil rata-rata yaitu $45,59375^{\mathrm{c}} \mathrm{cm}$. Perlakuan $\mathrm{P} 1$, P3 dan P4 lebih tinggi dari perlakuan P0 (kontrol). Pertumbuhan tinggi tanaman pada perlakuan P0 (kontrol) lebih pendek, dengan rata-rata yaitu $25,7625^{\mathrm{a}} \mathrm{cm}$ pada hari ke $35 \mathrm{HST}$. Hasil Analisis tinggi Ipomoea reptans Poir menggunakan SPSS 16.0 Uji GLM (General Linear Models) diperoleh 0,000 < 0,05, maka hasil tersebut signifikan, sehingga dapat diketahui bahwa pemberian POC kotoran sapi dan limbah tahu hasil produksi biogas dengan perlakuan berbeda, dapat mempengaruhi pertumbuhan tinggi Ipomoea reptans Poir (Gambar 1).

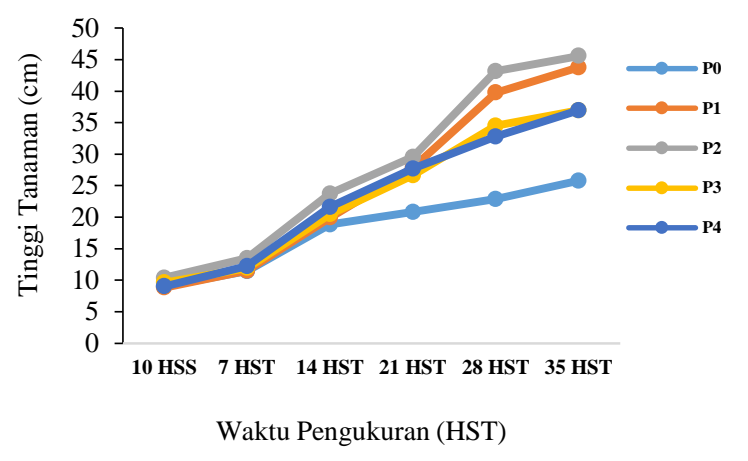

Gambar 1. Hasil pengamatan pertumbuhan Tinggi pada Ipomoea reptans Poir

Pertumbuhan tinggi Ipomoea reptans Poir terlihat berbeda nyata pada hari ke 14 HST hingga 35 HST. Optimalisasi penyerapan unsur hara $\mathrm{N}$ sudah optimal pada waktu tertentu (Bramasto et al., 2020). Grafik diatas menunjukan perlakuan P2 lebih dominan pada pertumbuhan tinggi Ipomoea reptans Poir. Penelitian Bramasto et al., (2020), menjelaskan bahwa urin sapi dan limbah cair tahu dapat meningkatkan pertumbuhan. Pemberian konsentrasi 40\% (P2) menunjukan pertumbuhan lebih tinggi bila dibandingkan dengan pemberian pupuk kotoran sapi dan limbah industri tahu dengan konsentrasi 20\% (P1), 60\% (P3), 80\% (P4). Nurbaiti et al., (2017) menjelaskan bahwa unsur hara $\mathrm{N} 1,24 \%$, memiliki pengaruh terhadap proses vegetasi tanaman. Sedangkan Hafizah et al., (2017) juga mengemukakan bahwa kotoran sapi yang mempunyai kadar serat yang tinggi seperti selulosa.

Penambahan tinggi tanaman pada perlakuan P2 Ipomea reptans Poir memiliki korelasi dengan pemberian POC hal ini menyebabkan pembelahan dan perbesaran sel, penlitian, Parman, (2007) melaporkan bahwa secara antiklinal, aktivitas meristematic pada bagian tubuh tumbuhan dipengaruhi oleh POC yang mengandung unsur $\mathrm{N}, \mathrm{P}, \mathrm{K}, \mathrm{Mg}$ dan $\mathrm{Ca}$ ) mempercepat proses terpacunya pembelahan dinding sel dan sintesis yang menjadikan peningkatan tinggi tanaman. Kandungan dalam POC terdiri atas $1,24 \%$ unsur nitrogen memiliki korelasi terhadap pertumbuhan tanaman (Anggraeni, 2018).

Jumlah Daun Tanaman Ipomoea reptans Poir Perhitungan jumlah daun Ipomoea reptans Poir dilakukan dengan menghitung daun yang telah terbuka sampurna, dihitung mulai dari 10 HSS hinga 35 HST (Grafik 2).

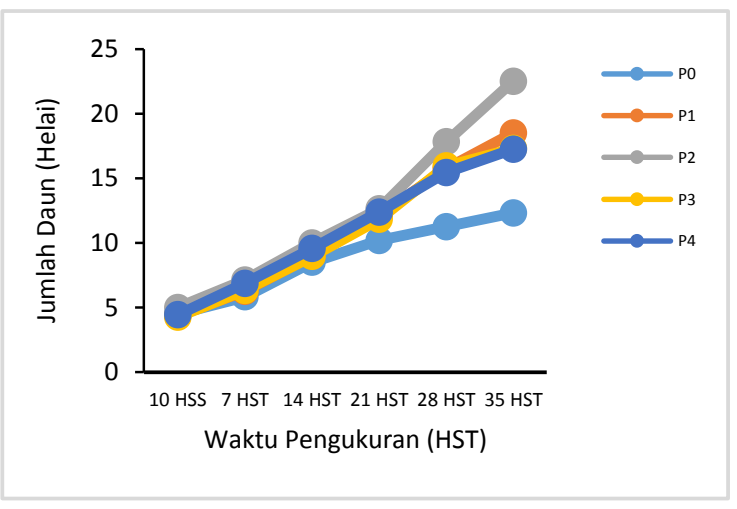

Gambar 2. Jumlah daun Ipomoea reptans Poir

Perlakuan P0 (kontrol) mengalami pertumbuhan jumlah daun relatif lambat perlakuan lainnya sedangkan P2 menunjukan peningkatan jumlah daun yang nyata (28 HST-35 HST). Perlakukan ini memberikan pengaruh yang berbeda nyata terhadap parameter jumlah daun Ipomoea reptans Poir yaitu perlakuan $\mathrm{P} 0=$ $\left(12,3125^{\mathrm{a}}\right), \mathrm{P} 1=\left(18,5^{\mathrm{b}}\right), \mathrm{P} 2=\left(22,5^{\mathrm{c}}\right), \mathrm{P} 3=$ $\left(17,3^{\mathrm{b}}\right)$ dan $\mathrm{P} 4=\left(17,25^{\mathrm{b}}\right)($ Tabel 4.2$)$. 
Tabel 2. Data Hasil Pengamatan Rata-Rata Jumlah Daun Ipomoea reptans Poir

\begin{tabular}{ccccccc}
\hline \multirow{2}{*}{ Perlakuan } & \multicolumn{5}{c}{ Rata-Rata Jumlah Daun Tanaman Kangkung Darat (Ipomoea reptans Poir) } \\
\cline { 2 - 6 } & 10 HSS & 7 HST & 14 HST & 21 HST & 28 HST & 35 HST \\
\hline P0 & 4,5 & $5,8125^{\mathrm{a}}$ & $8,5^{\mathrm{a}}$ & $10,1875^{\mathrm{a}}$ & $11,25^{\mathrm{a}}$ & $12,3125^{\mathrm{a}}$ \\
P1 & 4,3725 & $6,25^{\mathrm{a}}$ & $9^{\mathrm{ab}}$ & $12,125^{\mathrm{b}}$ & $15,75^{\mathrm{b}}$ & $18,5^{\mathrm{b}}$ \\
P2 & 5 & $7,125^{\mathrm{c}}$ & $10^{\mathrm{c}}$ & $12,625^{\mathrm{b}}$ & $17,8125^{\mathrm{b}}$ & $22,5^{\mathrm{c}}$ \\
P3 & 4,25 & $6,3125^{\mathrm{ab}}$ & $8,9375^{\mathrm{ab}}$ & $11,8125^{\mathrm{b}}$ & $15,9375^{\mathrm{b}}$ & $17,3^{\mathrm{b}}$ \\
P4 & 4,4375 & $6,8625^{\mathrm{bc}}$ & $9,5625^{\mathrm{ab}}$ & $12,375^{\mathrm{b}}$ & $15,4375^{\mathrm{b}}$ & $17,25^{\mathrm{b}}$ \\
\hline
\end{tabular}

Keterangan: Nilai rata-rata yang diberi superscrip menunjukan bahwa hasil tersebut signifikan, menurut Uji DMRT (Duncan's Mutiple Range Test)

Rata-rata jumlah daun Ipomoea reptans Poir paling dominan pada hari ke $35 \mathrm{HST}$ adalah perlakuan P2 dengan jumlah daun sebanyak $22,5^{\mathrm{c}}$ helai. Jumlah daun paling sedikit terdapat pada perlakuan P0 (kontrol) dengan jumlah daun sebanyak $12,3125^{\text {a }}$ helai. Perlakuan P0 berbeda nyata dengan perlakuan P1, P2, P3 dan P4. Perlakuan P1 tidak berbeda nyata dengan perlakuan $\mathrm{P} 3$ dan $\mathrm{P} 4$, tetapi perlakuan $\mathrm{P} 2$ berbeda nyata dengan perlakuan $\mathrm{P} 1, \mathrm{P} 3, \mathrm{P} 4$ dan $\mathrm{P} 0$ (kontrol). Pemberian POC di setiap perlakuan terdapat pada perlakuan P2 lebih dominan pertumbuhan jumlah daun Ipomoea reptans Poir dengan rata-rata yaitu $22,5^{\mathrm{c}}$ helai, dengan konsentrasi POC yang diberikan $40 \%$. Hasil analisis SPSS 16.0 Uji GLM (General Linear Models) diperoleh $0,000<0,05$ maka hasil tersebut signifikan. Uji lanjut yaitu Uji DMRT (Duncan's Mutiple Range Test), diketahui bahwa pemberian POC kotoran sapi dan limbaha industri tahu hasil produksi biogas dengan perlakuan berbeda berpengaruh nyata terhadap pertumbuhan jumlah daun Ipomoea reptans Poir. Haryadi et al., (2015) melaporkan bahwa daun muda lebih cepat mencapai bentuk yang sempurna. Perlambatan pertumbuhan daun disebabkan oleh kekurangan unsur hara (Alfi Roidi, 2016). Hal tersebut sangat terlihat pada perlakuan P0 (kontrol) yang sama sekali tidak diberikan POC kotoran sapi dan limbah industri tahu hasil produksi biogas. Firmansyah et al., (2017) proses pertumbuhan daun disebabkan karena daun menjadi pusat fotosintesis. Daun merupakan bagian tanaman yang memiliki manfaat terhadap perlindungan wilayah tanaman (Timba dan Bare, 2021).

\section{Produktivitas Berat Basah (Berat Segar) Ipomoea reptans Poir}

Pengukuran berat segar Ipomoea reptans Poir dilakuakan pada waktu panen (35 HST). Pada setiap perlakuan, terdapat empat individu. Keempat individu tanaman tersebut ditimbang satu persatu dengan menggunakan neraca tiga lengan sebagai alat timbang berat basah Ipomoea reptans Poir pada perlakuan tersebut dengan satuan ukuran gram $(\mathrm{g})$. Bagian tanaman yang di timbang yaitu keseluruhan Ipomoea reptans Poir yang meliputi akar, batang dan daun (Tabel 3). Tanaman yang paling berat adalah perlakuan P2 dengan konsentrasi pupuk $40 \%$ dan tanaman yang berat segarnya paling rendah yaitu perlakuan P4 dengan konsentrasi pupuk $80 \%$, dan P0 dengan konsentrasi pupuk 0\% (kontrol) (Tabel 3).

Tabel 3. Data Hasil Pengamatan Berat Basah Ipomoea reptans Poir

\begin{tabular}{cccccc}
\hline \multirow{2}{*}{ Kelompok } & \multicolumn{5}{c}{ Berat basah $(\mathbf{g})$} \\
\cline { 2 - 6 } & $\mathbf{P 0}$ & $\mathbf{P 1}$ & $\mathbf{P 2}$ & $\mathbf{P 3}$ & $\mathbf{P 4}$ \\
\cline { 2 - 5 } & 1,475 & 16,125 & 14,725 & 8 & 6,175 \\
2 & 2,825 & 13,1 & 17,125 & 10,65 & 7,275 \\
3 & 4,625 & 14,225 & 21,35 & 7,175 & 6,525 \\
4 & 3,475 & 19,975 & 16,55 & 14,775 & 12,025 \\
Total & 12,4 & 63,425 & 69,75 & 40,6 & 32 \\
Rata-rata & $\mathbf{3 , 1 0}$ & $\mathbf{1 5 , 8 5 6 2 5}^{\mathbf{c}}$ & $\mathbf{1 7 , 4 3 7 5}^{\mathbf{c}}$ & $\mathbf{1 0 , 1 5}^{\mathbf{b}}$ & $\mathbf{8}^{\mathbf{b}}$ \\
\hline
\end{tabular}


Keterangan: Nilai rata-rata yang diberi tanda superscrip dari masing-masing perlakuan menunjukan bahwa hasil tersebut signifikan, menurut hasil Uji DMRT (Duncan's Mutiple Range Test)

Hasil analisis SPSS 16.0 Uji GLM (General Linear Models) diperoleh 0,000 < 0,05 maka hasil tersebut signifikan. Uji lanjut yaitu Uji DMRT (Duncan's Mutiple Range Test), diketahui bahwa pemberian POC kotoran sapi dan limbah industri tahu hasil produksi biogas dengan perlakuan berbeda berpengaruh nyata terhadap parameter pengukuran berat basah Ipomoea reptans Poir. Hasil menunjukan bahwa perlakuan P2 dengan rata-rata yaitu $\left(17,4375^{c}\right)$ lebih dominan pada parameter pengkuran berat segar, sedangkan perlakuan yang memiliki berat segar paling rendah yaitu perlakuan P0 dengan rata-rata $3,10^{\text {a }}$. Berat segar Ipomoea reptans Poir sangat dipengaruhi oleh tinggi tanaman, jumlah daun dan jumlah air yang terkandung pada tanaman sesuai dengan pernyataan Sholikhah, (2019) bahwa bobot segar tanaman berkaitan erat dengan jumlah air yang terkandung dalam tubuh tanaman. Eka Widianti, (2020) juga menyatakan bahwa hal yang mempengaruhi berat segar tanaman adalah kandungan air didalam organ tanaman baik pada akar, batang, dan daun. Penelitian Kartika Dewi, (2020), mengemukakan bahwa semakin tinggi tanaman, maka jumlah daun akan semakin banyak, begitu pula dengan berat basah tanaman, semakin tinggi pertumbuhannya semakin tinggi juga nilai berat tanaman tersebut.

\section{Kesimpulan}

Berdasarkan hasil analisis dan pembahanan disimpulkan Pemberian POC dari kotoran sapi dan limbah industri tahu hasil limbah produksi biogas berpengaruh nyata terhadap pertumbuhan Ipomoea reptans Poir yang meliputi pertumbuhan tinggi tanaman dan jumlah daun serta hasil produtivitas Ipomoea reptans Poir. Konsentrasi POC terbaik dalam meningkatkan pertumbuhan dan produktifitas tanaman Ipomoea reptans Poir adalah perlakuan P2 dengan konsentrasi POC $40 \%$.

\section{Ucapan Terima Kasih}

Terima kasih kepada kepada Direktorat Jenderal Pendidikan Tinggi, Riset dan Teknologi, Kemendikbudristek yang memberikan kepercayaan insetif melalui
Program Talenta Inovasi Indonesia.

\section{Referensi}

Abdillah, B. S. (2017). Pengaruh Pemberian Pupuk Cair Paitan Dan Kotoran Sapi Sebagai Nutrisi Tanaman Kailan (Brassica Oleraceae Var. Alboglabra) Dalam Sistem Hidroponik. Jurnal Produksi Tanaman, 5, 8.

Affandi, M. R., Utami, S. N. H., \& Putra, N. S. (2018). Vermikompos Ampas Tahu Dan Kotoran Sapi Untuk Meningkatkan Ketersediaan N Dan Pertumbuhan Sawi Pakcoy Pada Inceptisol Berbah, Sleman. Naskah Publikasi Ilmiah, 14.

Ahmad, N. I., Bunga, Y. N., \& Bare, Y. (2019). Etnobotani Tanaman Cabai Merah Keriting (Capsicum Annum L.) Di Desa Waiwuring, Kecamatan Witihama Kabupaten Flores Timur. Spizaetus: Jurnal Biologi dan Pendidikan Biologi, 2(2), 10.

Alfi Roidi, A. (2016). Pengaruh Pemberian Pupuk Cair Daun Lamtoro (Leucaena leucocephala) Terhadap Pertumbuhan Dan Produktivitas Tanaman Sawi Pakcoy (Brasicca chinensis L.). Universitas Sanata Dharma Yogyakarta.

Anggraeni, I. (2018). Pemberian Pupuk Organik Cair Dan Pupuk Organik Padat Terhadap Pertumbuhan Tanaman Sawi (Branssica juncea). Fakultas Tarbiyah Dan Keguruan Universitas Islam Negeri Raden Intan Lampung.

Arba'i, A. (2021). Potensi Limbah Cair Tahu Sebagai Pupuk Organik Cair Tanaman Sawi Kailan. Universitas Sumatera Utara Medan.

Bramasto, Y., Suharti, T., Balai Penelitian dan Pengembangan Teknologi Perbenihan Tanaman Hutan, Mindawati, N., \& Pusat Penelitian dan Pengembangan Hutan. 
(2020). Utilization of Cow's Urine and Tofu's Liquid Waste for Growth of Leucaena Leucocephala Seedlings. Jurnal Perbenihan Tanaman Hutan, 8(2), 145157.

https://doi.org/10.20886/bptpth.2020.8.2. $145-157$

Eka Widianti, Y. (2020). Efektivitas Pemberian Pupuk Organik Cair Batang Pisang Dan Ab-Mix Terhadap Pertumbuhan Kangkung Darat (Ipomoea reptans Poir) Dan Kangkung Air (Ipomea aquatica) Secara Hidroponik. Program Studi Pendidikan Biologi Fakultas Keguruan Dan Ilmu Pendidikan Universitas Muhammadiyah Surakarta.

Fadhlillah, R. H., Dwiratna, S., \& Amaru, K. (2019). Performance of Floating Raft Fertigation System on Water Spinach Plants (Ipomea reptans Poir.) Cultivation. Jurnal Pertanian Tropik, 6(2), 165-179. https://doi.org/10.32734/jpt.v6i2.3124

Febriyono, R., Susilowati, Y. E., \& Suprapto, A. (2017). Peningkatan Hasil Tanaman Kangkung Darat (Ipomoea Reptans, Poir) Melalui Perlakuan Jarak Tanam Dan Jumlah Tanaman Per Lubang. Jurnal Ilmu Pertanian Tropika dan Subtropika, 6. https://doi.org/DOI (pdf): http://dx.doi.org/10.31002/vigor.v2i1.323 .g257

Firmansyah, I., Syakir, M., \& Lukman, L. (2017). Pengaruh Kombinasi Dosis Pupuk N, P, dan K Terhadap Pertumbuhan dan Hasil Tanaman Terung (Solanum melongena L.). Jurnal Hortikultura, 27(1), 69. https://doi.org/10.21082/jhort.v27n1.2017 .p69-78

Hafizah dan Mukarramah, N. dan abiatul. (2017). Aplikasi Pupuk Kandang Kotoran Sapi Pada Pertumbuhan Dan Hasil Tanaman Cabai Rawit (Capsicum frustescens L.) Di Lahan Rawa Lebak. Majalah Ilmiah Pertanian, 42. https://doi.org/DOI: http://dx.doi.org/10.31602/zmip.v42i1.63 6
Haryadi, D., Yetti, H., \& Yoseva, S. (2015). Effect Of Some Types Fertilizeron The Growth And Production. Departement Of Agrotechnology, Faculty Of Agriculture, University Of Riau, 2, 10.

Hidayat, T. (2019). Respon Tanaman Kangkung Darat (Ipomoea reptans Poir) Terhadap Konsentrasi Pupuk Organik Cair Nasa. Fakultas Pertanian Universitas Andalas Padang, 50.

Irawati, I., \& Salamah, Z. (2013). Pertumbuhan Tanaman Kangkung Darat( Ipomoea reptans Poir.) Dengan Pemberian Pupuk Organik Berbahan Dasar Kotoran Kelinci. Jurnal Bioedukatika, 1(1), 3. https://doi.org/10.26555/bioedukatika.v1i 1.4079

Kartika Dewi, A. (2020). Efektivitas Pupuk Organik Cair (POC) Dari Batang Pisang Terhadap Pertumbuhan Bayam Hijau (Amaranthus sp.) Dan Bayam Merah (Alternanthera ficoides) Secara Hidroponik. Progam Studi Pendidikan Biologi Fakultas Keguruan Dan Ilmu Pendidikan Universitas Muhammadiyah Surakarta.

Krisnamurti, G. C., Sari, D. R. T., \& Bare, Y. (2021). Capsaicinoids from Capsicum annuum as an Alternative FabH Inhibitor of Mycobacterium Tuberculosis: In Silico Study. Makara Journal Of Science, 25(4), 9. https://doi.org/10.7454/mss.v25i4.1248

Manuel, J. (2017). Pembuatan Pupuk Organik Cair Dari Limbah Air Kelapa Dengan Menggunakan Bioaktivator, Azotobacter chroococcum dan Bacillus mucilaginosus. Departemen Teknik Kimia Fakultas Teknologi Industri Institut Teknologi Sepuluh Nopember Surabaya.

Nurbaiti, Arnis, Ahmad Nurbaiti, \& Yulia, Al Amin. (2017). Pemanfaatan Limbah Cair Tahu Untuk Pertumbuhan Dan Produksi Tanaman Pakcoy ( Brassica rapa L.). 
Journal Mahasiswa Fakultas Pertanian Universitas Riau.

Parman, S. (2007). Pengaruh Pemberian Pupuk Organik Cair terhadap Pertumbuhan dan Produksi Kentang (Solanum tuberosum L.). Laboraatorium Biologi Struktur dan Fungsi Tumbuhan Jurusan Biologi FMIPA UNDIP, 2, 11.

Putri, A. (2017). Pengaruh Metode Elektrolisis Terhadap Pertumbuhan Dan Produksi Tanaman Hidroponik Kangkung. Universitas Islam Negeri Raden Intan Lampung.

Qoniah, U. (2019). Pengaruh Pemberian Pupuk Cair Daun Gamal (Gliricidia Sepium) Terhadap Pertumbuhan Dan Produktivitas Tanamanselada (Lactuca Sativa L.)Dengan Media Hidropoik. Universitas Islam Negeri Raden Intan Lampung.

Sari, D. R. T., \& Bare, Y. (2020). Physicochemical properties and biological activity of bioactive compound in Pepper nigrum: In silico study. Spizaetus: Jurnal Biologi dan Pendidikan Biologi, 1(2), 1-6.

Sholikhah, I. (2019). Pengaruh Pemberian Pupuk Cair Organik dan Pupuk Cair Kimia terhadap Pertumbuhan Tanaman Sawi (Brassica juncea L.) dengan Metode Hidroponik Sistem Wick. Universitas Negeri Surabaya, 8, 6.

Solihin, A. (2015). Pengaruh Variasi Kotoran Sapi (Padat dan Cair) dan Limbah Cair Tahu Terfermentasi Terhadap Pertumbuhan Tanaman Sawi (Brassica juncea L.) Dengan Teknik Hidroponik. Universitas Islam Negeri Sunan Kalijaga Yogyakarta.

Swastini, M. (2015). Pengaruh Arang Sekam Sebagai Media Tanam Terhadap Pertumbuhan Tanaman Kangkung Darat (Ipomoea reptans Poir). Universitas Sanata Dharma Yogyakarta.
Timba, F. N. S., \& Bare, Y. (2021). Program Pemulihan Pariwisata Jembatan dan Wisata Mangrov Desa Niranusa Kecamatan Maurole Kabupaten Ende. Jurnal ABDINUS: Jurnal Pengabdian Nusantara, $\quad 5(2)$, 8. https://doi.org/10.29407/ja.v5i2.16296

Zulfa, M. (2019). Pemanfaatan Limbah Cair Tahu Terhadap Pertumbuhan Bayam Merah (Alternantera amoena Voss) Dalam Kultur Hidroponik Rakit Apung. Universitas Islam Negeri Raden Intan Lampung. 